\title{
Quantum dots induce heat shock-related cytotoxicity at intracellular environment
}

\author{
Satoshi Migita • Alexandre Moquin • Hitomi Fujishiro • \\ Seiichiro Himeno • Dusica Maysinger • \\ Françoise M. Winnik • Akiyoshi Taniguchi
}

Received: 29 July 2013 / Accepted: 11 September 2013 /Published online: 3 October 2013 / Editor: T. Okamoto

(C) The Society for In Vitro Biology 2013

\begin{abstract}
Quantum dots (QDs) are semiconductor nanocrystals with unique optical properties. Different proteins or polymers are commonly bound to their surfaces to improve biocompatibility. However, such surface modifications may not provide sufficient protection from cytotoxicity due to photodegradation and oxidative degradation. In this study, the cytotoxic effects of QDs, CdTe, and CdSe/ZnS were investigated using cadmiumresistant cells. CdTe QDs significantly reduced cell viability, whereas, $\mathrm{CdSe} / \mathrm{ZnS}$ treatment did not markedly decrease the cell number. CdTe QDs were cytotoxic in cadmium-resistant cells suggesting that internalized QDs degraded and cadmium ions contributed to the cytotoxic effects. CdTe QDs were consistently more cytotoxic than CdSe/ZnS QDs, but both QDs as well as cadmium ions activated heat shock protein $70 \mathrm{~B}^{\prime}$ promoter. QDs themselves are likely to contribute to HSP70B'
\end{abstract}

S. Migita $(\varangle) \cdot$ A. Taniguchi

Biomaterials Unit, National Institute for Materials Science,

1-1 Namiki, Tsukuba, Ibaraki 305-0044, Japan

e-mail: migita@yz.yamagata-u.ac.jp

A. Moquin · F. M. Winnik

Faculty of Pharmacy and Department of Chemistry, University of

Montreal, Pavillon J.A. Bombardier, C.P. 6128 Succursale

Centre-Ville, Montreal, QC H3C 3J7, Canada

H. Fujishiro $\cdot$ S. Himeno

Laboratory of Molecular Nutrition and Toxicology, Faculty of

Pharmaceutical Sciences, Tokushima Bunri University,

Yamashiro-cho, Tokushima 770-8514, Japan

D. Maysinger

Department of Pharmacology and Therapeutics,

McGill University, Montreal, QC H3G 1Y6, Canada

F. M. Winnik $\cdot$ A. Taniguchi

WPI International Center for Materials Nanoarchitectonics

(WPI-MANA), National Institute for Materials Science,

1-1 Namiki, Tsukuba, Ibaraki 305-0044, Japan promoter activation in cadmium-resistant cells, because $\mathrm{CdSe} /$ $\mathrm{ZnS}$ QDs do not release sufficient cadmium to activate this promoter.

Keywords Quantum dots (QDs) · Cytotoxicity · Cadmium · Heat shock protein (HSP) $\cdot$ Nanomaterial

\section{Introduction}

Quantum dots (QDs) are semiconductor nanocrystals a few nanometers in diameter that are used extensively for in vitro observations of cellular mechanisms and for in vivo studies aimed at understanding the biodistribution of nanoparticles upon systemic injection (Bruchez et al. 1998; Chan et al. 2002; Alivisatos 2004). With the emergence of QDs detectable with light in the near IR window, clinical applications can be foreseen under certain situations (Pansare et al. 2012; Peng et al. 2012; Qian et al. 2012). The advantages of QDs over organic fluorescent dyes lie primarily in their high quantum yield, exceptional photostability, coupled with multicolor capability and size-tunable emission color. However, the most useful QDs contain toxic elements, mostly cadmium. Although QDs injection in animals does not trigger nefarious events over a limited timeline (up to a few mo) (Rak-Raszewska et al. 2012), concerns have risen about the long-term cytotoxicity of QDs as a consequence of slow degradation of the shell built around the CdSe core upon exposure to the biological milieu (Derfus et al. 2004; Michalet et al. 2005; Cho et al. 2007; Winnik and Maysinger 2013).

From the numerous studies of QD cytotoxicity, it has emerged that one of the possible mechanism responsible for the QDs toxicity involves the formation of reactive oxygen species (ROS) through cadmium ions released within cells by degradation of internalized QDs core. Photogeneration of free 
radicals upon irradiation of QDs has also been invoked as a potential origin of QD-induced oxidative stress. (Lovric et al. 2005a, 2005b). Thus, Cho et al. found that QDs' cytotoxicity may not be attributed solely to the toxic effect of released cadmium ion, and concluded oxidative stress is generated both by free cadmium and by photooxidation processes to QDs in a polar aerobic environment (Cho et al. 2007). Moreover, Hoshino et al. gave strong evidence that QD toxicity is related to the chemical structure of the ligand bound to the QDs surface molecules (Hoshino et al. 2004).

Heat shock protein (HSP)70 is a suitable gene for the construction of sensor cells. Kato et al. described that HSP expression is useful for the investigation of biological responses to biomaterials (Kato et al. 1997, 1998, 2001). We established a stress-response element in the heat shock protein 70B' (HSP70B') gene and, using this functional element with reporter genes, detected cadmium chloride and a wide range of cytotoxic stimuli (Wada et al. 2005, 2007; OkudaShimazaki et al. 2007).

In this study, we used cadmium-resistant cells to investigate (1) if QDs in the absence of measurable amounts of free cadmium ions reduce cell viability and (2) to reveal the mechanism involved in QD-induced cell death. The cells had down-regulated Zrt/Irt-related protein (ZIP) 8 transporter, which is associated with cadmium ion uptake (Yanagiya et al. 1999; Fujishiro et al. 2009). In these cells, the transport of cadmium ion through the cell membrane is prevented. Hence, a cytotoxic response of cadmium-resistant cells, if detected, must be induced by cadmium ions released by QDs after cellular uptake. The viability of cadmium-resistant cells treated with $\mathrm{CdTe}$ or $\mathrm{CdSe} / \mathrm{ZnS}$ QDs was assessed by watersoluble tetrazolium salts-1 (WST-1) assay for cell counting. The activation of heat shock protein $70 \mathrm{~B}^{\prime}$ promoter by the two types of QDs was achieved by employing the luciferase reporter gene assay. Our results strongly support the hypothesis that, even in the absence of internalized cadmium ions, QDs lead to cell death in naive and in cadmium-resistant cells by activation of the HSP70B' promoter, a well-established marker for the heat shock-induced cellular impairments.

\section{Materials and Methods}

Materials. Cysteamine-coated CdTe and CdSe/ZnS QDs were synthesized, purified, and characterized as described previously (Al-Hajaj et al. 2011). Their physicochemical properties are presented in Table 1 . The emission wavelength and the particle diameter were 564 and $3.17 \mathrm{~nm}$ for CdTe and 614 and $4.72 \mathrm{~nm}$ for CdSe/ZnS. Both QD samples had $\zeta$-potential of $\sim+40 \mathrm{mV}$.

Cell culture. Metallothionein-null cadmium-resistant cells were established by a previous paper (Yanagiya et al. 1999).
Table 1 Physicochemical property of QDs.

\begin{tabular}{llll}
\hline Quantum dots & $\lambda_{\mathrm{em}}(\mathrm{nm})$ & Diameter $(\mathrm{nm})$ & $\zeta$-potential $(\mathrm{mV})$ \\
\hline CdTe-Cys & 564 & 3.17 & +41.9 \\
CdSe/ZnS-Cys & 614 & 4.72 & +41.9 \\
\hline
\end{tabular}

Cadmium-resistant cells, which were from metallothionein KO-mouse cells, were selected by $\mathrm{CdCl}_{2}$ resistant. Cadmium-resistant cells were down-regulated ZIP8 transporter. NIH/3T3 cells, cadmium-resistant cells, and parental cells were cultured in Dulbecco's modified Eagle's medium containing 4,500 mg/L glucose (Sigma-Aldrich, St. Louis, MO) and supplemented with $10 \%$ fetal bovine serum, penicillin, and streptomycin. Cultured cells were maintained at $37^{\circ} \mathrm{C}$ in a humidified atmosphere containing $5 \% \mathrm{CO}_{2}$, and the media were changed every $2-3 \mathrm{~d}$.

Cell viability test. Cells were seeded at $1 \times 10^{4}$ cells per well into the 96-well plate. After incubation, cells were treated with either a solution of $\mathrm{CdCl}_{2}$ or QDs solution for $24 \mathrm{~h}$. CellCounting Kit solution (Doujin Chemical Co., Kumamoto, Japan) was added to each well, and then were incubated for $2 \mathrm{~h}$ at $37^{\circ} \mathrm{C}$. The principle of this kit is measurement of water-soluble formazan generated from reduction of WST by mitochondrial activity. The absorbance at $450 \mathrm{~nm}$ was measured in xMark microplate reader (Bio-Rad Laboratories, Hercules, CA).

Luciferase reporter assay. Luciferase reporter plasmid, pHSP-Luc which contained HSP70B' promoter -287 to + 118-bp region (Wada et al. 2007; Migita et al. 2010), was used to analyze the ability of either $\mathrm{CdCl}_{2}$ or QDs sample to induce the cytotoxic response within cells. Cadmium-resistant cells and parental cells were co-transfected with $250 \mathrm{ng}$ pHSPLuc, $25 \mathrm{ng}$ of pRL-CMV (renilla luciferase control plasmid; Promega Corp., Madison, WI) using Lipofectamine LTX (Invitrogen, Carlsbad, CA). At $12 \mathrm{~h}$ after transfection, cells were exposed to $\mathrm{CdCl}_{2}$ or QDs solution, and were incubated for $12 \mathrm{~h}$. Then, cells were lysed in $1 \times$ lysis buffer (Promega) and luciferase, and renilla light units were measured in Lumat LB9507 (Berthold Technologies, Bad Wildbad, Germany) luminometer according to the manufacturer's protocol for the Dual Luciferase assay (Promega).

Confocal microscopic observation. Confocal laser scanning microscopy was carried out using a Zeiss LSM510 microscope (Carl Zeiss, Inc., Oberkochen, Germany). One day before treatment of QDs, cadmium-resistant cells and parental cells were cultured on the cover slips (13-mm diameter; Matsunami Glass Ind., Ltd., Osaka, Japan). The concentration of $10 \mu \mathrm{g} / \mathrm{mL}$ CdTe QDs was added to the cells, and they incubated for $6 \mathrm{~h}$. After incubation, the cells were 
washed with PBS, and fixed with 4\% paraformaldehyde for $5 \mathrm{~min}$, and then they were stained lysosome, mitochondria, and nuclei by 50 -nM LysoTracker Red DND-99 (Invitrogen), 500-nM MitoTracker Deep Red 633 (Invitrogen), and $1 \mu \mathrm{g} /$ $\mathrm{mL}$ Hoechst33342 (Doujin Chemical) for $30 \mathrm{~min}$ at $\mathrm{CO}_{2}$ incubator, respectively. Figures were created using NIH Image J software.

Statistical analysis. Three samples $(n=3)$ were used for cell viability test and luciferase reporter assay. One-way ANOVA was used to examine the differences among different groups.

\section{Results}

First, we evaluated the cytotoxicity of the CdTe and the CdSe/ $\mathrm{ZnS}$ conjugated with cysteamine by the WST-1 assay. In preliminary experimentation, the peak value of cell damage was 18 to $24 \mathrm{~h}$ after QDs exposure. The time course of cell damages by QDs was similar to cadmium chloride. Therefore, we checked the cell viability in $24 \mathrm{~h}$ after QDs exposure. Treatment of NIH/3T3 cells with either CdTe or CdSe/ZnS QDs led to a concentration-dependent reduction in cell viability after $24 \mathrm{~h}$ of exposure (Fig. 1). The viability of cells treated with $\mathrm{CdSe} / \mathrm{ZnS}$ exceeded $80 \%$ at concentrations below $10 \mu \mathrm{g} /$ $\mathrm{mL}$, but the viability of cells treated with CdTe QDs drastically decreased upon treatment with QDs of concentration as low as $0.5 \mu \mathrm{g} / \mathrm{mL}$.

Figure 2 shows the viability of cadmium-resistant cells and parental cells treated either with QDs or a $\mathrm{CdCl}_{2}$ solution. Treatment of cells with cadmium chloride $(0.5$ and $1 \mu \mathrm{M})$ for $24 \mathrm{~h}$, significantly reduced the viability of parental cells, but it had no cytotoxic effect on cadmium-resistant cells. Treatment of parental or cadmium-resistant cells with $\mathrm{CdSe} / \mathrm{ZnS}$ QDs $(10 \mu \mathrm{g} / \mathrm{mL}, 24 \mathrm{~h})$ hardly affected their viability. In contrast, the viability of cadmium-resistant and parental cells treated with CdTe QDs $(10 \mu \mathrm{g} / \mathrm{mL}, 24 \mathrm{~h})$ decreased remarkably and to a similar extent.

To unravel the mechanism underlying the toxicity of $\mathrm{CdTe}$ QDs towards cadmium-resistant cells, it was necessary to determine the cellular localization of QDs in cadmiumresistant and parental cells. The cells exposed CdTe QDs was morphological change in $12 \mathrm{~h}$. Then we observed cellular localization of QDs at $6 \mathrm{~h}$. Imaging of cells by confocal laser microscopy was performed on cells subjected to a 6-h exposure to QDs. QDs were predominantly localized in lysosomes for both cadmium-resistant and parental cells (Fig. $3 a$ and $d$ ). Furthermore, small amounts of QDs could be detected in mitochondria and in the nucleus (Fig. 3).

To estimate the effect on cellular stress, we determined HSP70B' gene promoter activation in cells exposed to QDs using a reporter assay system. In preliminary experimentation,

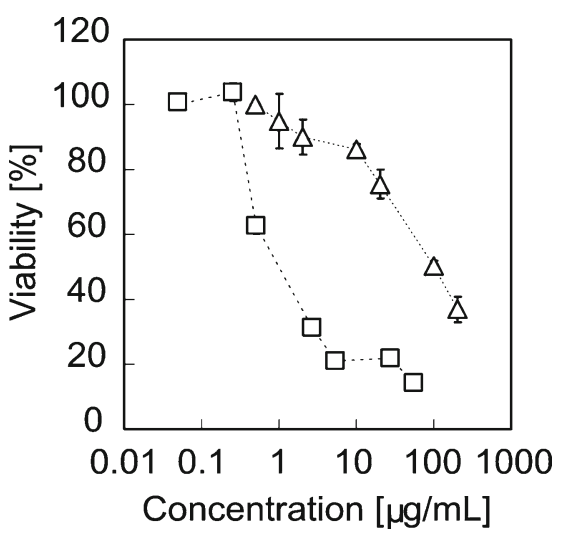

Figure 1 Viability of $\mathrm{NIH} / 3 \mathrm{~T} 3$ cells treated with cysteamine conjugated CdTe (squares) and $\mathrm{CdSe} / \mathrm{ZnS}$ (circles). The cells were exposed to anionic QDs samples for $24 \mathrm{~h}$ in serum-free media. Values represent mean $\pm \mathrm{SD}(n=3)$.

the peak value of HSP70B' gene promoter activation was $12 \mathrm{~h}$ after QDs exposure. Therefore, we checked the HSP70B' gene promoter activation in $12 \mathrm{~h}$ after QDs exposure. Figure 4 shows the activity of engineered HSP70B' gene promoter of cadmium-resistant cells treated either with QDs or with cadmium chloride. There was no effect on the HSP70B' gene expression when the cells were treated with cadmium chloride. Treatment of cells with $10 \mu \mathrm{g} / \mathrm{mL}$ CdTe for 12 -h induced luciferase activity (expressed as relative luminescent units) in cadmium-resistant cells; however, although $\mathrm{CdSe} / \mathrm{ZnS}$ QDs did not release cadmium ions, they slightly enhanced HSP promoter activity.

\section{Discussion}

The viability of cadmium-resistant cells treated with CdTe or $\mathrm{CdSe} / \mathrm{ZnS}$ QDs was assessed by a WST-1 assay for cell counting. The activation of heat shock protein $70 \mathrm{~B}^{\prime}$ promoter by the two types of QDs was achieved by employing the luciferase reporter gene assay. Our results strongly support the hypothesis that, even in the absence of internalized

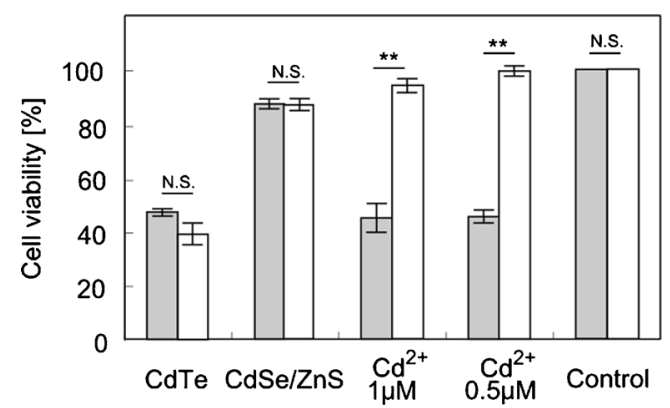

Figure 2 Viability of cadmium-resistant cells (open bar) and its parental cells (closed bar) treated with QDs samples $(10 \mu \mathrm{g} / \mathrm{mL})$, with $\mathrm{CdCl}_{2}$ aqueous solutions and control (without chemicals) for $24 \mathrm{~h}$. Values represent mean $\pm \mathrm{SD}(n=3)$. 
Figure 3 Confocal fluorescent microscopic image of the $\mathrm{Cd}^{2+}$ resistant cells $(a-c)$ and parental cells $(d-f)$ treated with CdTe QDs $(10 \mu \mathrm{g} / \mathrm{mL})$ for $6 \mathrm{~h} . a$ and $d$ show colocalization (yellow) of QDs (green) and lysosome (red); $b$ and $e$ show colocalization (yellow) of QDs (green) and mitochondria (red); $c$ and $f$ show colocalization (light blue) of QDs (green) and nuclei (blue). The arrows point colocalized regions of QDs and each organelle.
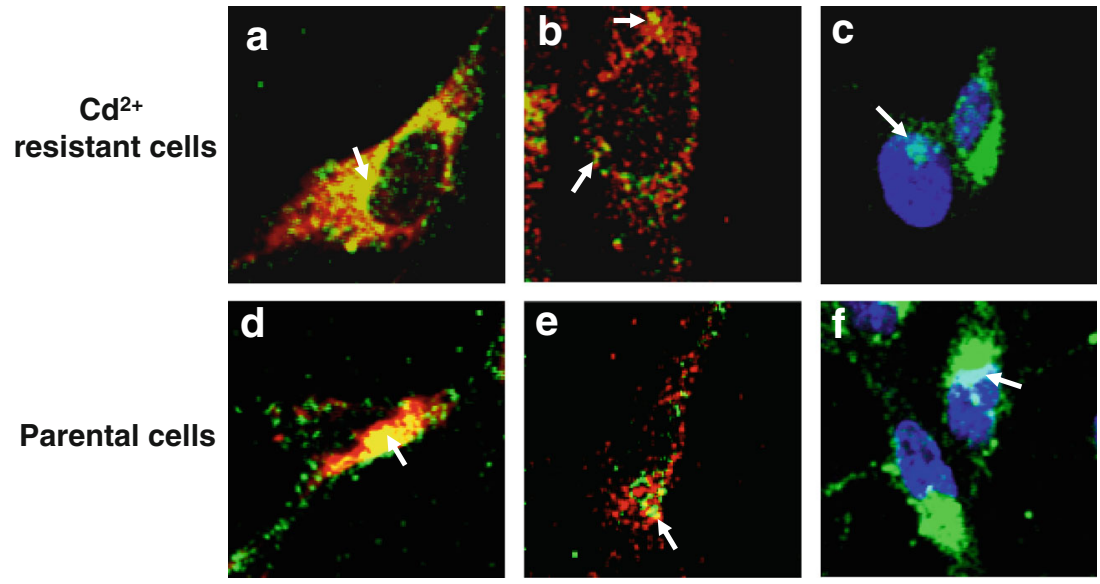

QD-Lysosome

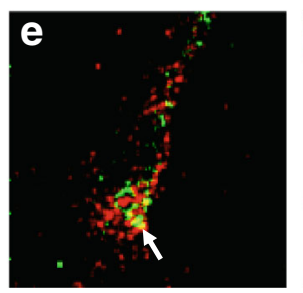

QD-Mitochondria

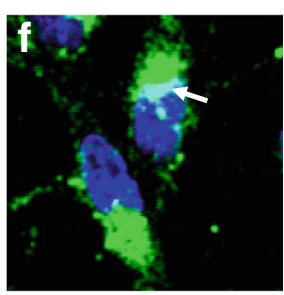

QD-Nuclei cadmium ions, QDs lead to cell death in naive and in cadmium-resistant cells by activation of the HSP70B' promoter, a well-established marker for the heat shock-induced cellular impairments.

In vitro cytotoxicity of $Q D$ s. In the first stage of our investigation, we evaluated the cytotoxicity of CdTe and $\mathrm{CdSe} / \mathrm{ZnS}$ QDs conjugated with cysteamine by the WST-1 assay. The CdTe QDs led to a highly significant reduction of NIH/3T3 cells viability. We hypothesized that the cytotoxic effect caused by CdTe QDs is largely due to the release of free cadmium upon degradation of their outer surface in the cell culture medium. In contrast, $\mathrm{CdSe} / \mathrm{ZnS}$, are much more stable and free cadmium is barely detectable in the extracellular medium or inside the cells.

The aim of this study was to provide new insights in the origin of QD cytotoxicity in the intracellular environment through the use of cadmium-resistant cells, an approach that has not been reported as yet, although it is highly relevant in this situation. In our experiments, the viability of both parental and cadmium-resistant decreased upon treatment with $\mathrm{CdTe}$ QDs $(10 \mu \mathrm{g} / \mathrm{mL}, 24 \mathrm{~h})$. On the other hand, both cell types

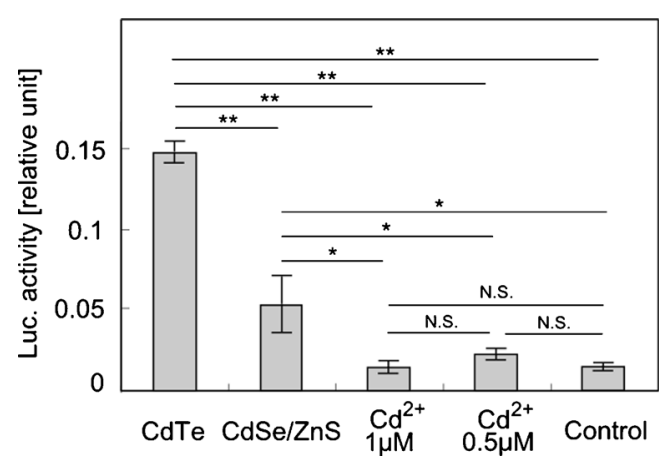

Figure 4 HSP promoter activity in cadmium-resistant cells treated with QDs samples $(10 \mu \mathrm{g} / \mathrm{mL})$, and $\mathrm{CdCl}_{2}$ solutions for $12 \mathrm{~h}$ as measured by luciferase reporter gene assay. The luciferase activities are indicated as relative values and represent mean $\pm \mathrm{SD}(n=3)$. demonstrated substantial resistance against $\mathrm{CdSe} / \mathrm{ZnS}(10 \mu \mathrm{g} /$ $\mathrm{mL}, 24 \mathrm{~h}$ ), implying that these QDs were not contaminated with cadmium ion prior to use and, more importantly, that they did not release cadmium ions in the cellular environment, at least within the time frame of this measurement. Furthermore, QDs were most often found at lysosome, in agreement with previous findings by Cho et al. 2007. Hence, the QD-induced cytotoxicity is expected to be initiated within these organelles. Moreover, Cho et al. determined intracellular cadmium ion at the QDs exposure condition (Cho et al. 2007). For CdTe QDs $(10 \mu \mathrm{g} / \mathrm{mL}, 24 \mathrm{~h})$ exposure, the intracellular cadmium concentration is similar level to cadmium chloride $(1 \mu \mathrm{M}, 24 \mathrm{~h})$ exposure. On the contrary, there was no cadmium ion for CdSe/ZnS QDs (10 $\mu \mathrm{g} / \mathrm{mL}, 24 \mathrm{~h}$ ) exposure. Our data strongly support these previous findings.

Evocation of heat shock stress by QDs. Normally, HSP70B' is induced by cadmium ion ( $\mathrm{Wu}$ et al. 1986; Feder and Hofmann 1999). We reasoned that if the QDs do not release cadmium within cellular organelles or the cytosol, HSP70B' could not be activated. We observed that both CdTe and the $\mathrm{CdSe} / \mathrm{ZnS}$ QDs induced the promoter activity. This result suggests the dependence of the CdTe Qds-induced cytotoxicity on the intracellular free cadmium ions possibly released from lysosome. However, $\mathrm{CdSe} / \mathrm{ZnS}$ do not release the cadmium ion in intracellular environment, as described by Cho et al. 2007. It is known that the expression of HSP70B' is induced by cadmium ions, but it is also regulated by other cytotoxic stimulations (Schlesinger 1990; Kiang and Tsokos 1998), such as protein denaturation (Welch 1992) or ROS (Ma et al. 1998; Gorman et al. 1999). Actually, there is no denying that ROS can be generated from the QDs surface (Winnik and Maysinger 2013). The generated ROS from the QDs surface possibly induces heat shock stress. Recent research reports point to the fact that nanoparticles, other than QDs, can affect protein conformation/folding (Shang et al. 2007), protein aggregation/fibrillation (Linse et al. 2007; Chen et al. 2012), 
Figure 5 Schematic representation of mechanistic pathways for HSP70B' expression by QDs. HSP70B' expression is evoked following conformational change of heat shock factor (HSF) caused by both cell-incorporated QDs or/ and $\mathrm{Cd}^{2+}$ released from QDs.

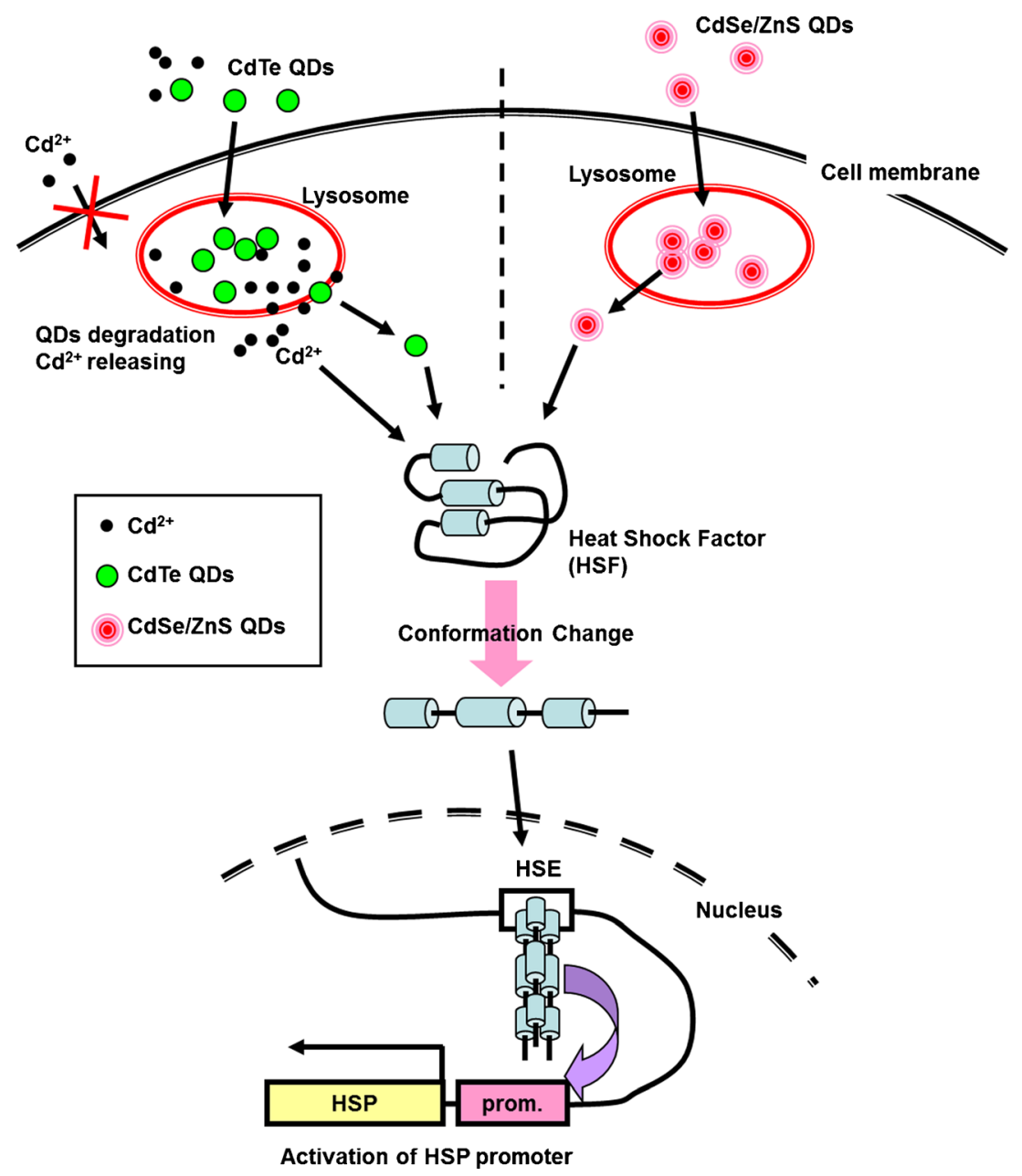

and production of ROS (Uchino et al. 2002; Li et al. 2003). Hence, our observations may be taken as an indication that $\mathrm{CdSe} / \mathrm{ZnS}$ QDs, themselves, can trigger similar in vitro reactions as a consequence of their size and that the HSP activity observed is the outcome of this effect.

Mechanism for cytotoxic effect of QDs. Based on the results from these and previous studies, we propose the following tentative mechanism to account for the QD-triggered effect in cadmium-resistant cells (Fig. 5). Cadmium-resistant cells cannot uptake extracellular cadmium ion because the ZIP8 transporter is suppressed. However, the viability of cadmiumresistant cells decreased similarly to parental cells, when cells are treated with CdTe QDs. Therefore, it can be considered that the cytotoxicity towards cadmium-resistant cells is induced by CdTe QDs internalized by the cells. The incorporated CdTe QDs are localized within the lysosomes. They degrade under the oxidative cellular conditions and release cadmium ions. The released cadmium ions induce protein denaturation, and triggers HSP70B' promoter activation. On the other hand, $\mathrm{CdSe} / \mathrm{ZnS}$ QDs do not release cadmium ion. Nevertheless, they induce marked cell death following
HSP70B' expression, indicating that QDs may also induce protein denaturation or/and conformational changes. Hence the cytotoxic effect of QDs, related to the heat shock signal, is generated not only by released cadmium ions, but also QD nanocrystals themselves.

\section{Conclusions}

In this study, we investigated the reduction of cell viability by free cadmium ions of QDs and revealed the mechanism involved in QD-induced cytotoxicity using cadmium-resistant cells. CdTe QDs significantly reduced cell viability, whereas, $\mathrm{CdSe} / \mathrm{ZnD}$ treatment decreased slightly. Cytotoxicity of $\mathrm{CdTe}$ QDs in cadmium-resistant cells supported the internalized QDs degradation and cadmium ions release. Cytotoxicity of CdTe QDs was markedly greater than CdSe/ZnS QDs, but both QDs activated HSP70B' promoter. QDs themselves are likely to contribute to HSP70B' promoter activation and induced cytotoxic stress in the cells, because CdSe/ZnS QDs do not release sufficient cadmium to activate this promoter. 


\section{References}

Al-Hajaj N. A.; Moquin A.; Neibert K. D.; Soliman G. M.; Winnik F. M.; Maysinger D. Short ligands affect modes of QD uptake and elimination in human cells. ACS NANO 5: 4909-4918; 2011.

Alivisatos P. The use of nanocrystals in biological detection. Nat Biotechnol 22: 47-52; 2004

Bruchez Jr. M.; Moronne M.; Gin P.; Weiss S.; Alivisatos P. Semiconductor nanocrystals as fluorescent biological labels. Science 281: 2013-2016; 1998.

Chan W. C. W.; Maxwell D. J.; Gao X.; Bailey R. E.; Han M.; Nie S. Luminescent quantum dots for multiplexed biological detection and imaging. Curr Opin Biotechnol 13: 40-46; 2002.

Chen P.; Kanehira K.; Sonezaki S.; Taniguchi A. Detection of cellular response to titanium dioxide nanoparticle agglomerates by sensor cells using heat shock protein promoter. Biotechnol Bioeng 109: 3112-3118; 2012.

Cho S. J.; Maysinger D.; Jain M.; Roder B.; Hackbarth S.; Winnik F. M. Long-term exposure to CdTe quantum dots causes functional impairments in live cells. Langmuir 23: 1974-1980; 2007.

Derfus A. M.; Chan W. C. W.; Bhatia S. N. Probing the cytotoxicity of semiconductor quantum dots. Nano Lett 4: 11-18; 2004.

Feder M. E.; Hofmann G. E. Heat-shock proteins, molecular chaperones, and the stress response: Evolutionary and ecological physiology. Annu Rev Physiol 61: 243-282; 1999.

Fujishiro H.; Okugaki S.; Kubota K.; Fujiyama T.; Miyataka H.; Himeno $\mathrm{S}$. The role of ZIP8 down-regulation in cadmium-resistant metallothionein-null cells. J Appl Toxicol 29: 367-373; 2009.

Gorman A. M.; Heavey B.; Creagh E.; Cotter T. G.; Samali A. Antioxidant-mediated inhibition of the heat shock response leads to apoptosis. FEBS Lett 445: 98-102; 1999.

Hoshino A.; Fujioka K.; Oku T.; Suga M.; Sasaki Y. F.; Ohta T.; Yasuhara M.; Suzuki K.; Yamamoto K. Physicochemical properties and cellular toxicity of nanocrystal quantum dots depend on their surface modification. Nano Lett 4: 2163-2169; 2004.

Kato S.; Akagi T.; Kishida A.; Sugimura K.; Akashi M. Evaluation of biological responses to polymeric biomaterials by RT-PCR analysis.2. Study of HSP 70 mRNA expression. J Biomater Sci Pol Ed 8: 809-814; 1997.

Kato S.; Akagi T.; Sugimura K.; Kishida A.; Akashi M. Evaluation of biological responses to polymeric biomaterials by RT-PCR analysis III: Study of HSP 70; 90 and 47 mRNA expression. Biomaterials 19: 821-827; 1998

Kato S.; Matsuyama T.; Serizawa T.; Kishida A.; Akashi M. HSP 47 and collagen mRNA expression in L929 cells adhered to lipid films. $J$ Biomater Sci Pol Ed 12: 149-156; 2001.

Kiang J. G.; Tsokos G. C. Heat shock protein $70 \mathrm{kDa}$ : molecular biology, biochemistry, and physiology. Pharmacol Ther 80: 183-201; 1998.

Li N.; Sioutas C.; Cho A.; Sxhmitz D.; Misra C.; Sempf J.; Wang M.; Oberley T.; Froines J.; Nel A. Ultrafine particulate pollutants induce oxidative stress and mitochondrial damage. Environ Health Perspect 11: 455-460; 2003.

Linse S.; Cabaleiro-Lago C.; Cue W. F.; Lynch I.; Lindman S.; Thulin E.; Radford S. E.; Dawson K. A. Nucleation of protein fibrillation by nanoparticles. Proc Natl Acad Sci USA 104: 8691-8696; 2007.

Lovrc J.; Cho S. J.; Winnik F. M.; Maysinger D. Unmodified cadmium telluride quantum dots induce reactive oxygen species formation leading to multiple organelle damage and cell death. Chem Biol 12: $1227-1234 ; 2005 b$
Lovric J.; Bazzi H. S.; Cuie Y.; Fortin G. R. A.; Winnik F. M.; Maysinger D. Differences in subcellular distribution and toxicity of green and red emitting CdTe quantum dots. $J$ Mol Med 83: 377-385; $2005 \mathrm{a}$.

Ma Y. X.; Cao L.; Kawabata T.; Yoshino T.; Yang B. B.; Okada S. Cupric nitrilotriacetate induces oxidative DNA damage and apoptosis in human leukemia HL-60 cells. Free Radic Biol Med 25: 568-575; 1998.

Michalet X.; Pinaud F. F.; Bintolila L. A.; Tsay J. M.; Doose S.; Li J. J.; Sundaresan G.; Wu A. M.; Gambhir S. S.; Weiss S. Quantum dots for live cells, in vivo imaging, and diagnostics. Science 307: 538 544; 2005.

Migita S.; Wada K. I.; Taniguchi A. Reproducible fashion of the HSP70B' promoter-induced cytotoxic response on a live cell-based biosensor by cell cycle synchronization. Biotechnol Bioeng 107: 561-565; 2010.

Okuda-Shimazaki J.; Takaku S.; Kanehira K.; Sonezaki S.; Taniguchi A. Effects of titanium dioxide nanoparticle aggregate size on gene expression. Int J Mol Sci 11: 2382-2392; 2007.

Pansare V. J.; Hejazi S.; Faenza W. J.; Prud'homme R. K. Review of longwavelength optical and NIR imaging materials: contrast agents, fluorophores, and multifunctional nano carriers. Chem Mater 24: 812-827; 2012.

Peng C. W.; Tian Q.; Yang G. F.; Fang M.; Zhang Z. L.; Peng J.; Li Y.; Pang D. W. Quantum-dots based simultaneous detection of multiple biomarkers of tumor stromal features to predict clinical outcomes in gastric cancer. Biomaterials 33: 5742-5752; 2012.

Qian J.; Wang D.; Cai F.; Zhan Q.; Wang Y.; He S. Photosensitizer encapsulated organically modified silica nanoparticles for direct two-photon photodynamic therapy and in vivo functional imaging. Biomaterials 33: 4851-4860; 2012

Rak-Raszewska A.; Marcello M.; Kenny S.; Edgar D.; Sée V.; Murray P. Quantum dots do not affect the behaviour of mouse embryonic stem cells and kidney stem cells and are suitable for short-term tracking. PLOS ONE 7: e32650; 2012.

Schlesinger M. J. Heat shock proteins. J Biol Chem 265: 12111-12114; 1990.

Shang W.; Nuffer J. H.; Dordick J. S.; Siegel R. W. Unfolding of rebonuclease A on silica nanoparticle surface. Nano Lett 7: 1991$1995 ; 2007$.

Uchino T.; Tokunaga H.; Ando M.; Utsumi H. Quantitative determination of $\mathrm{OH}$ radical generation and its cytotoxicity induced by $\mathrm{TiO}_{2}$-UVA treatment. Toxicol Vitr 16: 629-635; 2002.

Wada K. I.; Taniguchi A.; Okano T. Highly sensitive detection of cytotoxicity using a modified HSP70B' promoter. Biotechnol Bioeng 97: 871-876; 2007.

Wada K. I.; Taniguchi A.; Xu L. M.; Okano T. Rapid and highly sensitive detection of cadmium chloride induced cytotoxicity using the HSP70B' promoter in live cells. Biotechnol Bioeng 92: 410-415; 2005.

Welch W. J. Mammalian stress response: cell physiology, structure/ function of stress proteins, and implications for medicine and disease. Physiol Rev 72: 1063-1081; 1992.

Winnik F. M.; Maysinger D. Quantum dot cytotoxicity and ways to reduce it. Acc Chem Res 46: 672-680; 2013.

Wu B. J.; Eingston R. E.; Morimoto R. I. Human HSP70 promoter contains at least two distinct regulatory domains. Proc Natl Acad Sci USA 83: 629-633; 1986.

Yanagiya T.; Imura N.; Kondo Y.; Himeno S. Reduced uptake and enhanced release of cadmium in cadmium-resistant metallothionein null fibroblasts. Life Sci 65: 177-182; 1999. 